\title{
Resistance to the Pink Stem Borer in Twenty Exotic Maize Populations Under Natural and Artificial Infestation Conditions
}

\author{
Khamis I. Khalifa ${ }^{1}$, Tamer A. E. Abdallah ${ }^{1} \&$ Adel M. E. Elrawy ${ }^{2}$ \\ ${ }^{1}$ Maize Research Department, Field Crops Research Institute, Agriculture Research Center, Giza, Egypt \\ ${ }^{2}$ Field Crops Pests Research Department, Plant Protection Research Institute, Agriculture Research Center, Egypt \\ Correspondence: Khamis I Khalifa, Maize Research Department, Field Crops Research Institute, Agriculture \\ Research Center, Giza, Egypt. E-mail: khalifakh2010@yahoo.com
}

\author{
Received: February 26, 2013 Accepted: June 8, 2013 Online Published: July 15, 2013 \\ doi:10.5539/jas.v5n8p117 URL: http://dx.doi.org/10.5539/jas.v5n8p117
}

\begin{abstract}
Twenty exotic maize populations with different genetic background representing different geographical zones were obtained from Maize Gene Bank of Maize Res. Dept., Field Crops Res. Inst. (FCRI), Agric. Res. Center (ARC), Egypt. They were evaluated in 2011 to determine their level of resistance to the pink stem borer Sesamia cretica under natural infestation at Nubaria, Gemmeiza and Sakha Agric. Res. Stn. and under artificial infestation at Giza Agric. Res. Stn. A Randomized Complete Block Design was used. Evaluation trials under natural infestation were planted in the early summer (April) while under artificial infestation planting took place in the normal growing season (May). Three resistance expressing traits, i.e. percentage of infested plants (IP), percentage of plants with dead hearts (DH) and intensity of damage (ID) were used to evaluate the level of resistance in the twenty populations. Five-classes rating scale was developed to evaluate the intensity of damage caused by larvae of S. cretica. Results showed that, populations Tamps. 23 and Antigua have relatively good level of resistance to infestation by larvae of $S$. cretica. The two populations could be integrated into maize breeding programs which aim at developing hybrids resistant to $S$. cretica. Highly significant correlation coefficients were found among pairs of the three resistance expressing traits under artificial infestation. Correlation between results under natural and artificial infestation for the three studied traits showed low to moderate correlation which indicated that, for precise results on the level of resistance to $S$. cretica, evaluation should be made under artificial infestation conditions. In addition, exotic germplasm should be considered as a source for resistance genes in breeding programs for insect-pest resistance.
\end{abstract}

Keywords: pink stem borer, Sesamia cretica, natural and artificial infestation, correlation coefficients, exotic germplasm

\section{Introduction}

Maize is considered as one of the most important cereal crops in Egypt. It can play a major role in narrowing the present food gap via expansion in cultivation of maize hybrids with high yield potentiality and resistant to major diseases and insect pests affecting maize production.

In Egypt, maize plants are usually attacked by several injurious insect pests. The pink stem borer, Sesamia cretica Led. and the European corn borer, Ostrinia nubilalis (Hub.) are considered the major insects affecting maize productivity since they can cause great yield losses. James (2003) stated that $9 \%$ of the world maize crop is lost annually due to damage caused by insect pests. Oloyede et al. (2011) found that grain yield losses due to $S$. calamistis infestation ranged from $25-30 \%$.

The pink stem borer $S$. cretica is considered the most damaging corn borer in Egypt since it attacks young maize plants shortly after emergence, devours the whorl leaves and may kill the growing point causing complete death of small maize plants and consequently reducing number of plants at harvest causing drastic yield losses (Semeada, 1985; EL-Naggar, 1991; Soliman, 1994). This insect is also capable of damaging older plants through excavating tunnels into the stems, ears and/ or cobs. Yield reduction due to S. cretica depends on many factors including the stage at which the plant is infested, the insect population available for infestation in addition to the environmental conditions during the growing season. 
Several investigations were carried out to evaluate maize cultivars for their resistance to the pink stem borer, most of them were conducted in Egypt either under natural infestation (Simeada, 1985; EL-Sherif et al., 1986; Tantawy et al., 1989; Al-Naggar et al., 2000b; Soliman et al., 2001, Malver et al., 2007; Hemida et al., 2008) or under artificial infestation (EL-Sherif \& Mostafa, 1987; Al-Naggar et al., 2000b; Soliman et al., 2001; Sekhara et al., 2008; Oloyede, 2011; El-Rawy \& Abdalla, 2011; Santosh et al., 2012; Ismail, 2012) or under both natural and artificial infestation (Soliman, 1997; Soliman et al., 2001; Galal et al., 2002; Mosa \& Amer, 2004; Mourad \& El-Rawy, 2012). However, most researchers working on host plant resistance to corn borers other than S. cretica are convinced that artificial infestation is superior and more efficient than natural infestation for accurate differentiation among maize genotypes for their resistance to corn borers (Guthrie, 1982; Mihm, 1983a). However, in case where there is a need to screen a large number of maize genotypes and the environmental conditions allow for uniform and heavy infestation with larvae of S.cretica, evaluation under natural infestation would allow for obtaining primary evaluation of these genotypes especially if evaluation can be achieved over a wide range of environments. Later, artificial infestation can be performed but will be, in this case, with a smaller number of genotypes for results confirmation.

The objectives of the present investigation were to: 1- determine the level of resistance to $S$. cretica in 20 exotic maize populations under natural and artificial infestation conditions, 2-assess the consistency of resistance results obtained from both methods of evaluation and 3- to decide if any of these populations can be integrated into the national breeding program that aims at developing maize hybrids resistant to the pink stem borer.

\section{Materials and Methods}

Twenty exotic maize populations were chosen for the purpose of this investigation. They were obtained from the Gene Bank of Maize Research Department, Field Crops Research Institute (FCRI) Agriculture Research Center (ARC), Egypt. These populations have different genetic backgrounds representing different geographical zones (Table 4).

Planting of these populations under natural infestation of $S$. cretica was carried out at Nubaria $\left(29^{\circ} 30^{\prime}\right.$ longitude, and $30^{\circ} 54^{\prime}$ latitude), Gemmeiza ( $31^{\circ} 00^{\prime}$ longitude and $30^{\circ} 83^{\prime}$ latitude) and Sakha ( $30^{\circ} 98^{\prime}$ longitude and $31^{\circ} 11^{\prime}$ latitude), Agric. Res. Stn. of ARC on April $6^{\text {th }}, 19^{\text {th }}$ and $21^{\text {st }}, 2011$, respectively. Day temperatures during summer growing season are from $27-33^{\circ} \mathrm{C}$ at Nubaria and Sakha and from $29-35^{\circ} \mathrm{C}$ at Gemmeiza location. High humidity is normally prevailing during July-August. These planting dates were chosen so that the plants reach the growth stage most preferred by this insect and the moth emergence from hibernating larvae reached its maximum to assure maximum natural infestation (Ahmed \& Kira, 1960). These populations were also evaluated under artificial infestation of at Giza Agric. Res. Stn. of ARC. Sowing date for artificial infestation was on May $30^{\text {th }}, 2011$. This planting date was chosen to coincide with the time of minimum natural infestation and so, minimizing intervening of natural and artificial infestation which can affect obtained results. Artificial infestation was performed by newly hatched larvae artificially reared in the Corn Borers Lab of Maize Res. Dept., FCRI, ARC using the Bazoka equipment as a mechanical dispenser according to Mihm (1983 a). Infestation was applied two times to ten plants in each row at 20-25 days after planting at the early whorl stage. Splitting of infestation was to assure occurrence of infestation. Each plant received 8-10 larvae in each application.

Randomized Complete Block Design with four replicates was used in all testing locations. Plot size under natural infestation was 4 rows of $6 \mathrm{~m}$ length, $60 \mathrm{~cm}$ width, with hills spaced at $25 \mathrm{~cm}$, while for artificial infestation, the experimental plot was one row $4 \mathrm{~m}$ length, $70 \mathrm{~cm}$ width and $25 \mathrm{~cm}$ hill spacing. Technical recommendations for maize growing were applied except pest control which was entirely avoided. Required field data were recorded at all testing locations 35 days after planting in case of evaluation under natural infestation and after 15 days from infestation of plants when evaluation was carried out under artificial infestation.

Data were recorded under natural artificial infestation on the following traits using five-classes rating scale which can accurately differentiate among tested genotypes.

\subsection{Percentage of Infested Plants}

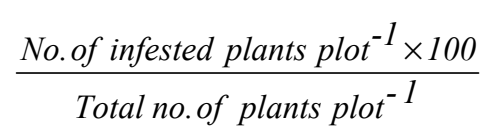

Genotypes were classified according to their mean percentage of infested plants into: Resistant, R (less than 30\%). Moderately Resistant, MR (from $30 \%$ to less than $40 \%$ ), Intermediate, I (from $40 \%$ to less than $50 \%$ ), Susceptible, S (from $50 \%$ to less than $60 \%$ ), and Highly Susceptible, HS (more than $60 \%$ ). 


\subsection{Percentage of Plants with Dead Hearts}

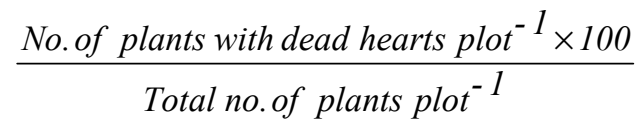

Genotypes were classified according to their mean percentage of plants with dead hearts into: Resistant, R (less than $8 \%$ ). Moderately Resistant, MR (from $8 \%$ to less than 12\%), Intermediate, I (from $12 \%$ to less than $16 \%$ ), Susceptible, S (from 16\% to less than 20\%), and Highly Susceptible, HS (more than 20\%).

\subsection{Intensity of Damage}

Five-classes rating scale was developed to evaluate the intensity of damage caused by attack of $S$. cretica larvae. The description of this scale is as follows:

Class 1: No visible injury on plants (no symptoms).

Class 2: Less than $25 \%$ of plants plot ${ }^{-1}$ is with holes less than $1 \mathrm{~mm}$ in diameter across partially or fully unfolded whorl leaves.

Class 3: Several folded and unfolded whorl leaves with relatively larger round and/or elongated holes accompanied with small yellowish green pillets of frass aggregated in the whorl.

Class 4: Plants with relatively larger round and/or elongated irregular holes, evident distortion of the leaves (most leaves have long holes), withering of whorl and accumulation of comparatively large sized pellets of frass in the whorl or on the ground around the stem.

Class 5: Plants with dead hearts.

The intensity of damage (ID) value for each plot was calculated as follows:

$$
\mathrm{ID}=\frac{\mathrm{ID} 1+\mathrm{ID} 2+\ldots \ldots \ldots \ldots \ldots+\text { IDn }}{\mathrm{N}}
$$

Where, $\mathrm{N}$ is the number of inspected plants.

Genotypes were classified according to their ID into: Resistant, R (less than 1.5), Moderately Resistant, MR (from 1.5 to less than 1.9), Intermediate, I (from 1.9 to less than 2.3), Susceptible, S (from 2.3 to less than 2.7), and Highly Susceptible, HS (more than 2.7).

Data that were collected in percentage were subjected to arcsine transformation for the purpose of statistical analysis. However, such data were presented hereafter in original percentages. Due to heterogeneity of error variances at the three testing locations, combined analysis was performed. Correlation coefficients among the three resistance expressing traits were also computed. All statistical analyses were performed according to Steel and Torrie (1980).

\section{Results and Discussion}

\subsection{Analysis of Variance}

Combined analyses of variance of the twenty maize populations for the three characters expressing maize plant resistance to Sesamia cretica (percentage of infested plants, percentage of plants with dead hearts, and intensity of plant damage) under natural infestation are presented in Table 1, while analysis of variance for the same characters under artificial infestation is presented in Table 2. Locations mean squares were highly significant for all studied traits (Table 1) indicating differences in the climatic conditions among the three testing locations at time of infestation which resulted in performance differences among the tested populations. Either significant or highly significant differences were detected among the 20 populations for the three resistance expressing traits under natural and artificial infestation (Tables 1 and 2). This indicated the presence of real differences in the genetic constitution of these populations concerning their level of resistance to infestation by the pink stem borer. Location $\times$ entry mean squares (Table 1) were highly significant for percentage of infested plants and plants with dead hearts which showed that the 20 populations behaved differently from one location to another and also indicated the importance of multilocation testing. 
Table 1. ANOVA analysis to evaluate significant differences among the twenty maize populations evaluated under natural infestation across three locations in 2011

\begin{tabular}{lllll}
\hline S.O.V. & d.f. & Infested Plants & Dead Hearts & Intensity of Damage \\
\hline Locations (Loc.) & 2 & $6491.9^{* *}$ & $6685.2^{* *}$ & $46.63^{* *}$ \\
Rep's (Loc) & 9 & $52.5^{* *}$ & $19.4^{*}$ & $0.42^{* *}$ \\
Populations (Pop) & 19 & $110.8^{* *}$ & $29.3^{* *}$ & $0.28^{*}$ \\
Loc $\times$ Pop & 38 & $39.9^{* *}$ & $32.1^{* *}$ & 0.21 \\
Error & 171 & 16.8 & 9.9 & 0.14 \\
\hline
\end{tabular}

Table 2. ANOVA analysis to evaluate significant differences among the twenty maize populations evaluated under artificial infestation in 2011

\begin{tabular}{lllll}
\hline S.O.V. & d.f. & Infested Plants & Dead Hearts & Intensity of Damage \\
\hline Replications & 2 & $232.53^{* *}$ & 1.94 & $0.116^{*}$ \\
Populations & 19 & $470.36^{* *}$ & $83.48^{* *}$ & $2.240^{* *}$ \\
Error & 38 & 15.81 & 1.63 & 0.027 \\
\hline
\end{tabular}

\subsection{Mean Performance of Populations}

Mean performances and insect reaction scores of the twenty populations under natural (combined) and artificial infestation are presented in Tables 3 and 4, respectively. Results for level of resistance under natural infestation, at separate locations, are presented in Table 5. Results varied considerably from one location to another where Sakha location had severe infestation while Nubaria location had the lowest and could not discriminate precisely among tested populations.

Table 3. Mean performance for percentage of infested plants, percentage of plants with dead hearts and intensity of damage under natural and artificial infestations of S. cretica, in 2011

\begin{tabular}{|c|c|c|c|c|c|c|c|}
\hline \multirow{2}{*}{ Entry No. } & \multirow{2}{*}{ Population } & \multicolumn{2}{|c|}{ Infested plants (\%) } & \multicolumn{2}{|c|}{ Plant with dead hearts (\%) } & \multicolumn{2}{|c|}{ Intensity of damage } \\
\hline & & Natural & Artificial & Natural & Artificial & Natural & Artificial \\
\hline 1 & V.55 & 30.8 & 43.9 & 19.8 & 26.4 & 2.03 & 2.62 \\
\hline 2 & Yellow Kenya & 31.9 & 42.2 & 17.9 & 23.4 & 2.18 & 2.48 \\
\hline 3 & Iowatigua- Tep 953 & 29.4 & 50.2 & 17.6 & 27.7 & 2.05 & 3.27 \\
\hline 4 & Carotigua-Tep 955 & 33.2 & 49.1 & 20.7 & 26.0 & 2.17 & 2.93 \\
\hline 5 & Tamps-8 & 29.5 & 45.0 & 15.9 & 21.7 & 2.05 & 2.39 \\
\hline 6 & Tamps-23 & 28.6 & 37.2 & 15.0 & 15.0 & 1.89 & 2.10 \\
\hline 7 & Thick Rind & 35.7 & 48.3 & 18.1 & 24.2 & 2.31 & 3.05 \\
\hline 8 & Antigua & 28.7 & 38.9 & 17.3 & 15.0 & 2.05 & 2.24 \\
\hline 9 & Westigua & 34.8 & 61.5 & 17.4 & 24.0 & 2.20 & 3.74 \\
\hline 10 & Pool-29 & 35.3 & 64.5 & 18.6 & 27.9 & 2.37 & 4.07 \\
\hline 11 & Pool-30 & 40.9 & 78.0 & 20.6 & 31.1 & 2.44 & 4.82 \\
\hline 12 & Pool-33 & 33.9 & 54.2 & 18.3 & 26.0 & 2.37 & 3.49 \\
\hline 13 & Pool-34 & 33.7 & 57.6 & 18.7 & 27.1 & 2.30 & 3.74 \\
\hline 14 & Mexico-207 & 31.9 & 55.9 & 16.9 & 24.8 & 2.04 & 3.57 \\
\hline 15 & Sonora GP.03 & 33.2 & 61.9 & 19.4 & 26.1 & 2.27 & 3.44 \\
\hline 16 & Guat-104 & 30.2 & 70.0 & 16.5 & 29.0 & 2.07 & 4.38 \\
\hline 17 & Managua-7432 & 33.9 & 64.2 & 18.4 & 27.3 & 2.18 & 3.81 \\
\hline 18 & Tep. 5 & 33.4 & 78.0 & 20.3 & 38.4 & 2.20 & 4.77 \\
\hline 19 & Tuxpeno & 31.3 & 70.3 & 16.2 & 32.8 & 2.11 & 4.65 \\
\hline 20 & Lancaster & 28.4 & 69.3 & 16.6 & 30.0 & 1.91 & 4.50 \\
\hline Mean & & 32.4 & 57.0 & 18.0 & 26.2 & 2.2 & 3.5 \\
\hline C.V. & & 12.6 & 7.0 & 17.4 & 4.9 & 17.6 & 4.7 \\
\hline $\operatorname{LSD}(0.05)$ & & 3.29 & 6.57 & 2.53 & 2.11 & 0.31 & 0.27 \\
\hline
\end{tabular}


Table 4. Pink stem borer resistances scores of the tested populations under natural (Nat.) and artificial (Art.) infestation across locations, in 2011

\begin{tabular}{|c|c|c|c|c|c|c|c|c|}
\hline \multirow{2}{*}{ Entry No. } & \multirow{2}{*}{ Pedigree } & \multirow{2}{*}{ Origin } & \multicolumn{2}{|l|}{ I.P. ${ }^{*}$} & \multicolumn{2}{|c|}{ D.H. } & \multicolumn{2}{|l|}{ I.D. } \\
\hline & & & Nat & Art & Nat & Art & Nat & Art \\
\hline 1 & V.55 & CIMMY $^{* *}$ & MR & I & $S$ & HS & I & $\mathrm{HS}$ \\
\hline 2 & Yellow Kenya & Kenya & MR & I & S & HS & I & HS \\
\hline 3 & Iowatigua- Tep 953 & CIMMYT & $\mathrm{R}$ & S & S & HS & I & HS \\
\hline 4 & Carotigua-Tep 955 & CIMMYT & MR & I & HS & HS & I & HS \\
\hline 5 & Tamps-8 & CIMMYT & $\mathrm{R}$ & I & I & HS & I & HS \\
\hline 6 & Tamps-23 & CIMMYT & $\mathrm{R}$ & MR & I & I & MR & I \\
\hline 7 & Thick Rind & USA & MR & I & S & HS & I & HS \\
\hline 8 & Antigua & CIMMYT & $\mathrm{R}$ & MR & S & I & I & I \\
\hline 9 & Westigua & CIMMYT & MR & S & S & HS & S & HS \\
\hline 10 & Pool-29 & CIMMYT & MR & S & S & HS & S & HS \\
\hline 11 & Pool-30 & CIMMYT & I & HS & HS & HS & S & HS \\
\hline 12 & Pool-33 & CIMMYT & MR & $\mathrm{S}$ & $\mathrm{S}$ & HS & S & HS \\
\hline 13 & Pool-34 & CIMMYT & MR & S & S & HS & I & HS \\
\hline 14 & Mexico-207 & CIMMYT & MR & S & S & HS & I & HS \\
\hline 15 & Sonora GP.03 & CIMMYT & MR & HS & S & HS & I & HS \\
\hline 16 & Guat-104 & CIMMYT & MR & HS & S & HS & I & HS \\
\hline 17 & Managua-7432 & CIMMYT & MR & HS & $\mathrm{S}$ & HS & I & HS \\
\hline 18 & Tep. 5 & CIMMYT & MR & HS & HS & HS & I & HS \\
\hline 19 & Tuxpeno & CIMMYT & MR & HS & $\mathrm{S}$ & HS & I & HS \\
\hline 20 & Lancaster & USA & $\mathrm{R}$ & HS & S & HS & I & HS \\
\hline
\end{tabular}

*. I.P., D.H., and I.D: Infested plants (\%), Dead hearts (\%) and intensity of damage, respectively.

${ }^{* *}$ CIMMYT: International Center for Maize and Wheat Improvement, located in El-Batan, Mixico. Genetic stocks introduced from CIMMYT represent mainly Latin American germplasm.

Table 5. Mean performance for resistance expressing traits at Nubaria, Gemmeza and Sakha research stations under natural infestation of $S$. cretica in 2011

\begin{tabular}{|c|c|c|c|c|c|c|c|c|c|c|c|c|c|c|c|c|c|c|c|}
\hline \multirow{3}{*}{\multicolumn{2}{|c|}{$\begin{array}{l}\text { Ent } \\
\text { no. }\end{array}$}} & \multicolumn{6}{|c|}{ Nubaria } & \multicolumn{6}{|c|}{ Gemmeiza } & \multicolumn{6}{|c|}{ Sakha } \\
\hline & & \multicolumn{2}{|c|}{ I.P.\% } & \multicolumn{2}{|c|}{ D.H.\% } & \multicolumn{2}{|l|}{ I.D. } & \multirow{2}{*}{\multicolumn{2}{|c|}{$\begin{array}{l}\text { I.P.\% } \\
\text { score scale }\end{array}$}} & \multirow{2}{*}{\multicolumn{2}{|c|}{ D.H.\% }} & \multirow{2}{*}{\multicolumn{2}{|c|}{$\begin{array}{l}\text { I.D. } \\
\text { escore scale }\end{array}$}} & \multirow{2}{*}{\multicolumn{2}{|c|}{$\begin{array}{l}\text { I.P.\% } \\
\text { score scale }\end{array}$}} & \multirow{2}{*}{\multicolumn{2}{|c|}{$\begin{array}{l}\text { D.H.\% } \\
\text { score scale }\end{array}$}} & \multicolumn{2}{|c|}{ I.D. } \\
\hline & & \multicolumn{6}{|c|}{ score scalescore scale score scale } & & & & & & & & & & & \multicolumn{2}{|c|}{ score scale score scalescore Scale } \\
\hline 1 & V.55 & 27.1 & $\mathrm{R}$ & 14.4 & I & 1.6 & MR & & $\mathrm{R}$ & 17.0 & $\mathrm{~S}$ & 1.8 & MR & 38.4 & MR & 28.1 & HS & 2.8 & HS \\
\hline 2 & Yellow Kenya & 27.6 & $\mathrm{R}$ & 12.3 & I & 1.5 & MR & 26.0 & $\mathrm{R}$ & 14.4 & I & 1.8 & MR & 42.2 & MR & 26.8 & HS & 3.2 & HS \\
\hline 3 & Iowatigua Tep 953 & 20.0 & $\mathrm{R}$ & 8.5 & MR & 1.5 & MR & 28.7 & $\mathrm{R}$ & 15.7 & I & 1.9 & I & 39.7 & I & 28.5 & HS & 2.8 & HS \\
\hline 4 & Carotigua Tep 955 & 27.3 & $\mathrm{R}$ & 17.6 & I & 1.8 & MR & 29.2 & $\mathrm{R}$ & 16.6 & $\mathrm{~S}$ & 1.8 & MR & 43.1 & MR & 27.8 & HS & 2.9 & HS \\
\hline 5 & Tamps-8 & 25.3 & $\mathrm{R}$ & 9.8 & MR & 1.5 & MR & 26.4 & $\mathrm{R}$ & 14.9 & I & 1.7 & MR & 36.9 & MR & 23.7 & HS & 2.8 & HS \\
\hline 6 & Tamps-23 & 26.9 & $\mathrm{R}$ & 9.1 & MR & 1.4 & MR & 25.3 & $\mathrm{R}$ & 16.0 & I & 1.7 & MR & 33.6 & MR & 20.8 & HS & 2.4 & HS \\
\hline 7 & Thick Rind & 28.6 & $\mathrm{R}$ & 9.7 & MR & 1.6 & MR & 34.1 & MR & 20.2 & $\mathrm{~S}$ & 2.3 & $\mathrm{~S}$ & 44.4 & $\mathrm{~S}$ & 24.5 & HS & 3.0 & HS \\
\hline 8 & Antigua & 19.5 & $\mathrm{R}$ & 9.8 & MR & 1.4 & MR & 30.9 & MR & 20.3 & S & 2.1 & I & 35.7 & I & 22.7 & HS & 2.6 & $\mathrm{~S}$ \\
\hline 9 & Westigua & 25.4 & $\mathrm{R}$ & 6.6 & $\mathrm{R}$ & 1.4 & MR & 34.6 & MR & 16.9 & $\mathrm{~S}$ & 2.1 & I & 44.5 & I & 28.6 & HS & 3.0 & HS \\
\hline & Pool-29 & 25.2 & $\mathrm{R}$ & 10.0 & MR & 1.5 & MR & 32.9 & MR & 16.0 & I & 2.4 & S & 47.8 & S & 29.5 & HS & 3.2 & HS \\
\hline & Pool 30 & 28.0 & $\mathrm{R}$ & 9.2 & MR & 1.6 & MR & 37.9 & MR & 16.7 & $\mathrm{~S}$ & 2.2 & I & 56.8 & I & 36.1 & HS & 3.5 & HS \\
\hline & Pool 33 & 26.0 & $\mathrm{R}$ & 7.2 & $\mathrm{R}$ & 1.5 & MR & 30.8 & MR & 19.1 & $\mathrm{~S}$ & 2.0 & I & 45.0 & I & 28.7 & HS & 3.7 & HS \\
\hline & Pool 34 & 24.4 & $\mathrm{R}$ & 9.8 & MR & 1.5 & MR & 32.5 & MR & 18.9 & $\mathrm{~S}$ & 2.3 & $\mathrm{~S}$ & 44.0 & $\mathrm{~S}$ & 27.5 & HS & 3.0 & HS \\
\hline & Mexico-207 & 23.5 & $\mathrm{R}$ & 7.5 & $\mathrm{R}$ & 1.5 & MR & 30.1 & MR & 15.1 & I & 1.8 & MR & 42.0 & MR & 28.2 & HS & 2.9 & HS \\
\hline & Sonora GP 03 & 28.4 & $\mathrm{R}$ & 10.6 & MR & 1.7 & MR & 28.0 & $\mathrm{R}$ & 18.5 & $\mathrm{~S}$ & 1.8 & MR & 43.2 & MR & 29.0 & HS & 3.3 & HS \\
\hline & Guate-104 & 20.1 & $\mathrm{R}$ & 7.1 & $\mathrm{R}$ & 1.4 & MR & 28.3 & $\mathrm{R}$ & 12.0 & I & 1.6 & MR & 41.5 & MR & 30.4 & HS & 3.1 & HS \\
\hline & Managua-7432 & 23.1 & $\mathrm{R}$ & 7.0 & $\mathrm{R}$ & 1.4 & MR & 31.8 & MR & 16.7 & $\mathrm{~S}$ & 1.8 & MR & 46.8 & MR & 31.4 & HS & 3.4 & HS \\
\hline & Tep-5 & 24.8 & $\mathrm{R}$ & 11.2 & MR & 1.6 & MR & 33.1 & MR & 19.6 & $\mathrm{~S}$ & 2.0 & I & 42.3 & I & 30.2 & HS & 3.0 & HS \\
\hline & Tuxpeno & 25.1 & $\mathrm{R}$ & 8.3 & MR & 1.6 & MR & 23.1 & $\mathrm{R}$ & 14.5 & I & 1.6 & MR & 45.6 & MR & 25.7 & HS & 3.1 & HS \\
\hline & Lancaster & 23.4 & $\mathrm{R}$ & 6.6 & $\mathrm{R}$ & 1.5 & MR & 26.0 & $\mathrm{R}$ & 17.5 & $\mathrm{~S}$ & 1.8 & MR & 35.3 & MR & 25.6 & HS & 2.4 & $\mathrm{~S}$ \\
\hline & Mean & 25.0 & & 9.5 & & 1.6 & & 30.0 & & 16.8 & & 1.9 & & 42.8 & & 27.7 & & 1.9 & \\
\hline & Scale & $\mathrm{R}$ & & MR & & MR & & MR & & $\mathrm{S}$ & & I & & I & & HS & & I & \\
\hline & C.V. & 14.2 & & 22.4 & & 14.9 & & 11.3 & & 17.2 & & 15.7 & & 12.0 & & 15.0 & & 18.0 & \\
\hline
\end{tabular}




\subsubsection{Infested Plants (\%)}

Results in Tables 3 and 4 showed that, under natural infestation, only five populations, i.e. Iowatigua, Tamps.8, Tamps.23, Antigua and Lancaster were significantly resistant, while all the other populations were moderately resistant except Pool 30 which was intermediate. However, under artificial infestation only two populations, i.e.Tamps.23 and Antigua were moderately resistant and five entries, i.e. V. 55, Yellow Kenya, Carotigua, Tamps.8, and Thick Rind were intermediate. No strong consistency was found for results of resistance under natural and artificial for this trait, indicating that selection of resistant genotypes should mainly depends on artificial infestation.

\subsubsection{Plants with Dead Hearts (\%)}

Results for resistance under natural infestation showed that populations Tamps. 8 and Tamps. 23 were intermediate while the other 18 populations were either susceptible or highly susceptible. Under artificial infestation, populations Tamps. 23 and Antigua were intermediate while the other populations were highly susceptible (Tables 3 and 4). Results of this trait under artificial infestation were, to some extent, similar to those under natural infestation.

\subsubsection{Intensity of Damage}

Results on intensity of damage (Tables 3 and 4) revealed that, under natural infestation only one population (Tamps. 23) was moderately resistant, 14 populations were of intermediate resistance, and five populations were susceptible. Results under artificial infestation showed that only two populations (Tamps. 23 and Antigua) were of intermediate resistance while the remaining populations were highly susceptible. Results showed also that, scores for the three resistance traits were much higher under artificial infestation as compared to those under natural infestation. This indicated that natural infestation in 2011, in general, was not severe enough to accurately assess the intensity of damage caused by larvae of S. cretica except at Sakha location, while artificial infestation had enforced good infestation pressure on the tested populations and was successful in discovering differences among them concerning resistance to infestation by larvae of $S$. cretica.

The top performing populations that behaved as resistant, moderately resistant or intermediate under both natural and artificial infestation were considered. Based on this criterion, populations Tamps. 23 and Antigua were considered of usefulness and could be integrated in the national maize breeding program for developing maize hybrids with resistance to infestation by larvae of S. cretica as well as high yield potentiality. Results revealed also that, out of the twenty exotic populations only two populations $(10 \%)$ had relatively good level of resistance to S.cretica.The role of exotic germplasm as a source for resistance to Sesamia spp.was investigated by many researchers. Burton et al. (1999) screened 121 exotic maize inbred lines representing seven germplasm groups and they found that only 7 inbred lines $(6 \%)$ were considered resistant to $S$. nonagrioidis. Santosh et al. (2012) evaluated 48 exotic inbred lines for resistance to $S$. inferences and found that only 8 inbred lines $(16 \%)$ were resistant. Mourad and El-Rawy (2012) evaluated 13 exotic sorghum lines for resistance to S. cretica and only one line $(8 \%)$ was found resistant. Results of this investigation indicated that natural infestation with $S$. cretica was not able to discriminate precisely between resistant and susceptible populations for the three resistance expressing traits. This conclusion was reached also by Soliman (1997) and Soliman et al. (2001). They indicated that maize breeders should depend only on artificial infestation in order to get precise results about the level of resistance to $S$. cretica in the genotypes under study. However, contradictory results were obtained by Tantawi et al. (1989) where they found that artificial infestation was successful in differentiating between resistant and susceptible hybrids. Also, Galal et al. (2002) indicated that natural infestation was suitable for studying the genetic behavior of resistance to the pink stem borer. Investigations of the last two researchers may be conducted in some years where environmental conditions allowed for high and uniform infestation levels.

Table 6. Correlation coefficients among pairs of the three resistance expressing traits under artificial and natural infestation, in 2011

\begin{tabular}{|c|c|c|c|c|c|c|}
\hline \multirow{2}{*}{ Traits } & \multicolumn{2}{|c|}{ I.P. } & \multicolumn{2}{|c|}{ D.H. } & \multicolumn{2}{|c|}{ I.D. } \\
\hline & Nat & Art & Nat & Art & Nat & Art \\
\hline Infested plants (\%), IP & -- & -- & $0.938^{* *}$ & $0.768^{* *}$ & $0.730^{* *}$ & $0.919 * *$ \\
\hline Dead heart plants (\%), DH & -- & -- & -- & -- & $0.572 * *$ & $0.827 * *$ \\
\hline Intensity of damage, ID & -- & -- & -- & -- & -- & -- \\
\hline
\end{tabular}


Table 7. Correlation coefficients between results under natural and artificial infestation for the three resistance expressing traits, in 2011

\begin{tabular}{llll}
\hline TRAIT & I.P. (natural) & D.H. (natural) & I.D. (natural) \\
\hline I.P. $^{+}$(artificial) & $0.475^{* *}$ & $\ldots$. & $\ldots$. \\
D.H. $^{+}$(artificial) & $\ldots$ & $0.331^{* *}$ & $\ldots$. \\
I.D. $^{+}$(artificial) & $\ldots$. & $\ldots$. & $0.262^{*}$
\end{tabular}

+ I.P., D.H., and I.D.: refer to infested plants (\%), plants with dead hearts (\%) and Intensity of damage, respectively.

\subsection{Correlation among Resistance Traits}

Simple correlation coefficients among pairs of the three resistance expressing traits, i.e. percentage of infested plants (IP), percentage of plants with dead hearts (DH) and intensity of damage (ID) are presented in Table 6 . Results showed that, under natural infestation, correlation coefficients between IP and DH, IP and ID, DH and ID were $0.94,0.73$ and 0.57 , respectively, while under artificial infestation, the correlation coefficients were $(0.77$, 0.92 and 0.83 ), respectively. Results confirmed the presence of highly significant positive correlation among the three traits and that; these positive correlations were higher, except for percentage of infested plants, under artificial infestation as compared to those under natural infestation conditions. These results indicated also that, only one or two of the three resistance expressing traits can be used in S. cretica resistance investigations. Using percentage of plants with dead hearts and intensity of plant damage should be enough in evaluation experiments for resistance to $S$. cretica. This is due to their effect on plant growth and number of plants at harvest and consequently obtained yield. Similar results were obtained by Odiyi (2007) who studied the effect of infestation by $S$. calamistis on grain yield and found moderate to high correlations among most pairs of resistance expressing traits.

Correlation coefficients between results under natural and artificial infestation for each of the three resistance expressing traits are presented in Table 7. Significant or highly significant positive correlation coefficients were obtained, but the correlation was not strong enough since the correlation values were low to moderate. This emphasizes the need for artificial infestation in order to get precise results for the level of resistance in any tested genotypes. Similar results were reported by Soliman (1997) who found low correlation between results under natural and artificial infestation by $S$. cretica.

\section{References}

Ahmed, K. A., \& Kira, M. T. (1960). Studies on corn borers and their control. Egypt. Agriculutre Org. Tech. Bull., $44,1-78$.

Al-Naggar, A. M., El-Ganayni, A. A., El-Lakany, M. A., El-Sherbeeny, H. Y., \& Soliman, M. S. M. (2000). Effectiveness of natural infestation in estimating genetic parameters conditioning inheritance of maize resistance to Sesamia cretica led. Egypt. Journal Plant Breed., 4, 37-53.

Burton, A., Malver, R. A., Cartea, M. E., Ordas, A., \& Velasco, P. (1999). Resistance of maize inbreds to pink stem borer. Crop Sci., 39, 102-107. http://dx.doi.org/10.2135/cropsci1999.0011183X003900010016x

El-Naggar, M. A. (1991). Ecological factors influencing some insect pests diversity in maize fields. M. Sc. Thesis , Fac. Agriculutre,Minufiya Univ., Egypt., 161.

El- Sherif, S. I, Mostafa, F. F., \& El-Negouly, O. O. (1986). Susceptibility of maize germplasm to infestation with the greater sugarcane borer Seasmia cretica led. Arab Journal Plant Protection, 4, 14-18.

El-Sherif, S. I., \& Mostafa, F. F. (1987). Susceptibility of maize germplasm to infestation with the greater sugarcane borer Seasmia cretica led. Arab Journal Plant Protection, 5, 8-13.

El-Rawy, A. M., \& Abdalla, T. A. (2011). A new simple method offered to maize breeders for rearing the pink stem borer Sesamia cretica larvae on a semi-artificial diet. Egypt. Journal Plant Breed., 15, 163-169.

Galal, A. A., El-Shenawy, A. A., \& Amer, E. A. (2002). Additive, dominance, and epistatic effects cotrolling resistance to Sesamia cretica led. In maize. Minufiya Journal Agriculutre Rescearch, Minufiya Univ., Egypt, 27, 1209-1215.

Guthrie, W. D. (1982). Progress update in Host Plant Resistance (European corn borer). Fifth Biennial Plant Resistance Workshop. Brownsville, Texas, USA. 
Hemida, E. A. M., Al-Naggar, A. M. M., El-Naggar, M. A. Z., \& Saad, El-Deen. (2008). Susceptibility of 20 maize cultivars to Sesamia cretica under natural infestation conditions. Annales Agriculutre Sci., Moshtohor, Banha Univ. Egypt., 46, 21-32.

Ismail, M. R. M. (2012). Geneticanalysisof agronomic charactersand resistance to borers in some genotypes of corn. Ph.D. Thesis, Agron.Dept., Fac. Agriculutre, BanhaUniv.,Egypt.

James, C. (2003). Global Review of Commercialized Transgenic Crops. (2002). Feature: Bt Maize. ISAAA, Breifs No. 29. The International Service for the Acquisition of Agribiotech Application. Itheca, NY., USA.

Malvar, R. A., Butron, A., Alvarez, A., Padilla, G., Cartea, M. E., Revilla, P., \& Ordas, A. (2007). Yield performance of the European Union maize landrace core collection under multiple corn borer infestation. Crop Protection, 26, 775-781. http://dx.doi.org/10.1016/j.cropro.2006.07.004

Mihm, J. A. (1983). Efficient mass rearing and infestation techniques for host plant resistance to maize stem borers (Diatraea sp.). CIMMYT, Mexico.

Mosa, H. A., \& Amer, E. A. (2004). A diallel analysis among maize inbred lines for resistance to pink stem borer and grain yield under artificial infestation and non-infestation.Annals Agriculutre Sci., Moshtohor, Banha Univ., Egypt, 42, 449-459.

Mourad, A. F. A. A., \& El- Rawy, A. M. (2012). Evaluation of some exotic sorghum lines for resistance to Sesamia cretica infestation and yield potential. Egypt. Journal Agriculutre Rescearch, 90, 1067-1077.

Odiyi, A. C. (2007). Relationships between stem borer resistance traits and grain yield reduction in maize: correlations, path analysis and correlated response to selection. Agriculutre Journal, 2, 337-342.

Oloyede-Kamiyo, Ajala, Q., \& Akoroda, M. D. (2011). Variability for resistance to the pink stem borer (Sesamia calamistis Hampson) and the sugarcane borer (Eldana saccharina Walker) in two tropical maize populations.Maydica, 56, 257-263.

Santosh, H. P., Sekhar J. C., SujayRakshit, Gadag, R. N., \& Sain, D. (2012). Detection of epistatic interaction for susceptibility toward pink borer (Sesamia inferences Walker) in maize. Indian Journal Genetics\& Plant Breed., 72, 284-289.

Sekhar, J. C., Sujay, R., Pradyumn, K., Mehrajuddin, A. M., \& Sain, D. (2008). Differential reaction of CIMMYT maize lines and their hybrid combinations to pink stem borer, Sesamia inference Walker. Annals Plant Protec. Sci., 16, 404-406.

Semeada, A. M. (1985). Relative susceptibility of certain maize germplasm to infestation with greater sugarcane borer Sesamia cretica led. M. Sc. Thesis, Fac. Agriculutre, Cairo Univ., Egypt.

Soliman, M. S. M. (1994). Corn borers affecting maize in Egypt. International Symbosium II on insect resistant maize. Recent Advances and Utilization. CIMMYT, Mexico (Nov. 27-Dec., pp. 276-278).

Soliman, M. S. M. (1997). Breeding studies on resistance to the corn borer Sesamia cretica led. in maize (Zea mays L.). Ph.D. thesis, Fac. Agriculutre, Cairo Univ., Egypt.

Soliman, M. S. M., Gaber, A. A. I., \& Khalifa, K. I. (2001). Natural vsartificial infestation in evaluation of maize hybrids for resistance to Sesamia cretica led. Journal Agriculutre Sci., 26, 3419-3433.

Steel, R. G., \& Torrie, J. H. (1980). Principles and Procedures of Statistics. New York, USA: Mc. Grow-Hill Book Co.

Tantawi, A. M., Sherif, M. R., \& Lutfellah, A. F. (1989). Resistance of certain maize cultivars to the pink beror, Sesamia cretica led. Infestation Proceed. $1^{\text {st }}$ Intl. Conf. Economic Entomology, 1, 271-275.

\section{Copyrights}

Copyright for this article is retained by the author(s), with first publication rights granted to the journal.

This is an open-access article distributed under the terms and conditions of the Creative Commons Attribution license (http://creativecommons.org/licenses/by/3.0/). 